China Perspectives

65 | may - june 2006

Varia

\title{
Russia: No Strategic Partnership With China in View
}

\section{Iliyas Sarsembaev}

\section{(2) OpenEdition \\ 12 Journals}

Édition électronique

URL : http://journals.openedition.org/chinaperspectives/631

DOI : 10.4000/chinaperspectives.631

ISSN : 1996-4617

Éditeur

Centre d'étude français sur la Chine contemporaine

\section{Édition imprimée}

Date de publication : 1 juin 2006

ISSN : 2070-3449

Référence électronique

\|liyas Sarsembaev, «Russia: No Strategic Partnership With China in View », China Perspectives [En ligne], 65 | may - june 2006, mis en ligne le 01 juin 2009, consulté le 28 octobre 2019. URL : http:// journals.openedition.org/chinaperspectives/631 ; DOI : 10.4000/chinaperspectives.631

Ce document a été généré automatiquement le 28 octobre 2019

(C) All rights reserved 


\title{
Russia: No Strategic Partnership With China in View
}

\author{
Iliyas Sarsembaev
}

12005 was rich in geopolitical and military events involving Russia in Central and East Asia: there were the Kaspiy Anti-Terror military manoeuvres of the Collective Security Treaty Organisation (CSTO) held in Kazakhstan in August ${ }^{1}$; the Andijan revolt in May followed by tensions between Uzbekistan and the United States and by a rapprochement between Moscow and Tashkent; the Sino-Russian manoeuvres in August; the Indo-Russian manoeuvres in October; all these punctuated by numerous journeyings by the Russian Defence Minister, Sergei Ivanov, across the region. What does this Russian activism signify? Is Moscow intending a return to the Asian and Central-Asian strategic stage? Do the Russians seek to create a regional alliance with, in particular, China and India, directed against the United States and its allies? Do these political manoeuvres portend an imminent jolt to the balance of forces in Asia?

2 The Andijan revolt, in May 2005, was reported by some Western journalists as a prodemocracy movement, ascribed by others to Islamists, or again, it was interpreted as an attempt to overthrow President Islam Karimov by a competing clan. Whatever the causes of that event, its direct consequences were the closure of the American base in Uzbekistan and the intensification of political repression against remaining political opponents, sharply criticised by Europe and the United States. In the Russian press, beyond all else, the Andijan events fed the theory that Tashkent was staging a return to Russia's sphere of geopolitical influence. Similarly, the joint Sino-Russian and IndoRussian military manoeuvres have also occasioned numerous articles, in the Russian press and on pro-government websites ${ }^{2}$, on the Kremlin's "new breakthrough" into the post-Soviet era and the renaissance of Russian power. The media applies itself to underlining the readiness of President Putin's team to restore the greatness of the Russian state, ravaged by the years of "savage democracy" (dikaya demokratizaciya) under Boris Yeltsin's leadership. But faced with this propaganda, various opposition movements, from communists to nationalists, criticise the "controlled decadence" (upravlyaemyi raspad) of the Russian state, at both the socio-economic and the military 
levels. On the domestic political scene, the insistence on Russia's alliances and its geopolitical successes is broadly aimed at containing this growing discontent.

This article seeks first of all to show that the Shanghai Co-operation Organisation $(\mathrm{SCO})^{3}$ is an attempt to create a political bloc that is not based on any solid legal foundation or on any mutual obligation linking the participating countries. Despite the manoeuvring of Russian diplomats to attract new members to the group, such as India and Iran, the prospects for converting the SCO into an effective structure are still rather vague. Whatever efforts the Russian government may be making to convert India to the idea of building a union between the three countries, there is no question of multilateral integration in the SCO structures: decision-making is still bilateral (Russo-Indian or Russo-Chinese). It is also important to take account of the fact that the Russian Foreign Affairs Ministry is at present better equipped for managing bilateral relations than multilateral relations: it operates through different departments and highly specialised services, and can count on few staff working to promote multilateral co-operation.

Secondly, the article describes the significant progress made towards consolidating military forces within the context of the Collective Security Treaty Organisation (CSTO). Yet, this organisation is far from forming a real politico-military bloc of exUSSR countries. It is no more than an attempt, on the part of the Russian Federation, to redefine its own area of influence. Moscow's initiatives in this sphere over these past two years show that building up the CSTO is being achieved far more rapidly and efficiently than the efforts towards integration within the SCO. But the acceleration of this process is coming up against several obstacles. In particular, there are tensions within the governing class as well as a lack of clear-sightedness or political will when it comes to the prospects for re-establishing power in the post-Soviet world. Indeed, the confrontation between the new elite ("new Russians", bankers, liberal businessmen, oligarchs) and the representatives of the old Soviet military-industrial complex does not favour the shaping of a clear national idea. Such internal tensions within Russian society also impede the smooth running of government agencies, and have a particularly deleterious effect on the financing of military programmes and the equipping of the federal armed services. These difficulties notwithstanding, the CSTO structures are much more active than the "amorphous mass" of the SCO: they make up the spine of what could come to be a military force, one that might, for example, intervene in cases of internal conflict within the Central-Asian space of the Commonwealth of Independent States (CIS). One such case was the CSTO's participation in the "pacification" of the situation in Bishkek, in March 2005, which kept chaos at bay in Kyrgyzstan ${ }^{4}$. Even so, it is still rather early to claim that Russia and the other members of the CSTO are on the eve of creating a real military union. This stage is not foreseeable without radical changes to the ideology that underlies Russian political life and without a greater affirmation of will by the CSTO members.

$5 \quad$ Finally, we shall emphasise that it takes more than mere willpower to create a political alliance. Russia cannot realistically claim to strengthen its strategic partnerships in Central and East Asia without resolving the serious problems affecting the national economy and the federal army. Otherwise, any political union can only change into an alliance between unequal partners: a strong China, a weak Russia and the handful of "spare parts" represented by the other countries of the former Soviet Union. So it is important to question the effective capacity of Russia to implement its plans for 
military integration, whether in the Central Asian area or within the Moscow-DelhiPeking relationship.

Towards a Sino-Indo-Russian alliance?

6 Some politicians yearn for the creation of a great coalition uniting India, Russia and China and capable of matching the power of the "Golden Billion", specifically Europe and the United States, whose people are rich economically but demographically weak ${ }^{5}$. The notion of strengthening Sino-Russian relations has been revived since the war in Yugoslavia, on the eve of Boris Yeltsin's political retirement. During his last visit to Peking, in 1998, the Russian President declared that the United States could not enforce its will on China and Russia. This declaration was taken by the Americans as a threat to create a Sino-Russian bloc, although Chinese diplomats swiftly distanced themselves from the idea. When Evgeny Primakov was Foreign Minister in 1999, Asia was a priority concern for Russian foreign policy. Even since his resignation, this former Prime Minister, now head of the Russian Chamber of Commerce and Industry, still wields decisive influence over Russia's policy towards Asia ${ }^{6}$. The dream of an alliance between three of the biggest and most populous countries on the planet, in which Moscow could again play a significant role, has its roots back in the time of the Comintern, when the Kremlin's emissaries were striving to create a military alliance with Sun Yat-sen's China. Yet, most Russian Sinologists ${ }^{7}$ exclude, in principle, any possibility of a union with China. They point, rightly, to the lessons of the history of Sino-Russian relations, marked by incessant conflicts ever since the sixteenth century ${ }^{8}$. The renaissance of a "Sino-Soviet friendship", as reflected in attempts at political and economic integration, could have catastrophic consequences for Russia. It would be forced into a situation of inferiority, given the central government's weak control over the Russian Far Eastern Federal District and the absence of a clear line on foreign policy. The plan for a close Sino-Russian alliance is further discredited by the fact that China has already repeatedly declared ${ }^{9}$ its opposition to forming a union with any other country-Russia included ${ }^{10}$.

7 Bringing India into a Sino-Russian union seems even less realistic. The alliance between China and India, whose frontier dispute is still not settled, is undermined by India's desire to control the situation in South Asia-in opposition to China's wishes. A RussoIndian rapprochement seems just as improbable: it is difficult to understand what Primakov may have been referring to when he spoke of the "coincidence of the interests of India and Russia in the Pacific area" ${ }^{11}$. The main raison d'être for any RussoIndian union would be as a defence against Chinese domination in the Pacific region ${ }^{12}$. If India did need to form a friendship with another geopolitical power in the Central Asian region, it would more probably be with the United States than with China or Russia. The recent Russo-Indian military manoeuvres ("Indra 2005"), October 16th 2005 , are admittedly a symbolic step towards realising Primakov's idea; but they were an extremely limited affair-only 130 Russian soldiers and 90 Indian soldiers actually took part.

8 Even so, information from sources within the CSTO in Moscow suggests that, in February 2006, the Russian Foreign Affairs Ministry opened discussions with Indian diplomats on the possibility of enlarging the SCO and on whether Delhi might possibly take part in its forums. There are two reasons behind the interest shown by India in joining this organisation. Firstly, because of the unstable situation created by the possibility of a military crisis over Iran, India is forced into seeking to secure, as quickly 
as possible, access to energy sources in post-Soviet Central Asia, sources whose availability would be guaranteed by some political and military mechanism: in an emergency, the CSTO institutions could be mobilised to ensure the security of gas and oil production in the region. Secondly, a war against Iran could destabilise India's neighbour Pakistan, where radical Islamists are influential: this could amount to a serious threat to the stability of the whole region. While the question of whether Iran possesses nuclear weapons remains hypothetical, Pakistan on the other hand does have a successfully tested nuclear device..., which might then fall into Islamist hands. Thus, although Washington strives to keep India within the sphere of its own Asian policy, the prospect of a big blow-up in Asia would tend rather to impel India towards a union with Russia and China. In these conditions, Primakov's dream of a great Russo-SinoIndian union, which could take shape under SCO auspices, appears less unrealisable, despite the rivalry between India and China over political and military domination in Asia. But it would take a considerable time to build up real mechanisms for management and decision-making ${ }^{13}$.

It appears then that one of the major factors limiting the possibilities for geopolitical alliance between Russia and other countries in Asia is the Kremlin's failure, ever since 1991, to develop a long-term regional strategy. Sociologically, the fact that the Russian elite is concentrated in Moscow contributes to their indecisiveness about the regions lying east of the Urals, of which their knowledge is very incomplete. Most Russian Sinologists, such as Viktor Larin ${ }^{14}$ or Yuri Galenovitch ${ }^{15}$, consider that the Russian government maintains very little control over the regions of the Russian Far East ${ }^{16}$. Russia cannot be ready for an alliance with China or India when it it is still at the stage of strengthening state control over the eastern part of its own territory.

A development in the Sino-Russian military balance of power unfavourable to Russia

The military factor is equally important in explaining the danger for Russia of an unbalanced union with China. The rundown in the Russian armed services since 1991 when combined with the strengthening of the Chinese army has altered the balance of power on the military level. The modernisation of the Russian army, as described in outline by Vladimir Putin in November 2005 at a meeting with staff officers of the federal army, seems for the present to be little more than words. Promises to modernise technical equipment between now and 2015 are no compensation for the fact that many servicemen are still being paid several months in arrears. Strengthening the Russian army seems to come down to saturation media coverage of a few token events: Putin in the cockpit of a Tu 160 nuclear bomber launching a new missile, Putin aboard the aircraft carrier Admiral Kuznetsov, Putin awarding medals to special forces officers, Putin visiting a nuclear submarine launching a missile ${ }^{17} .$. On this occasion, the official press omitted to point out that the missiles being launched by the President had been built in the late 1980s and were thus inherited from Soviet technology... As the journalist Vladislav Shurygin makes clear in the Zavtra review ${ }^{18}$, the development programme for strategic nuclear forces is today under threat of interruption. The Russian military-industrial complex has already lost more than two hundred strategic technologies, for lack of competent staff. Shurygin reports that, for lack of funding, the work of the Institute for Thermal Research has had to be suspended, which has already led to a halt in the production of Topol $\mathrm{M}$ and Bulava missiles. The article accuses two ministers of sabotage-German Gref, Economics Minister, and Alexey Kudrin, Finance Minister. Similarly, in 2005, the Defence Ministry purchased only seven missiles: so today there remain only 600 nuclear missiles to ensure Russia's defence, several of 
which are apparently urgently in need of modernisation. Of Russia's 20,000 tanks, approximately only half are in working order; and of Russia's 1,800 aircraft, about 1,200 are no longer capable of taking off. The worst of it is that a country that exports so much oil-and that is planning to increase its exports to China-refuses to provide its own air-force with fuel, thus preventing its pilots from training. Since 2000, efforts to modernise the armed services have been limited to the acquisition of $15 \mathrm{~T}-90$ tanks, 40 BTR- 80 armoured cars, 24 SU-27 aircraft, three TU-160 bombers and two KA-50 helicopters. In order to rebuild its military credibility in Asia, the Russian army would need 1,500 new T-90 tanks a year for ten years. When it comes to the navy, we should note that, since 2000, the Russian fleet has received not one new ship ${ }^{19}$. During the manoeuvres in the Pacific in 2004, the Russian fleet was even compelled urgently to recruit civilian mechanics for lack of competent staff. In December 2004, the Northern Fleet disgraced itself when, in front of President Putin, a nuclear submarine was found incapable of launching its missile. The C-50 anti-aircraft defence system is no longer even in a position to protect the airspace around Moscow or Russia's other industrial centres. These failings in the modernisation of the Russian armed forces are even more troubling in that they coincide with China's reinforcement of its People's Liberation Army, which has not given up the option of a massive deployment of tanks and infantry: the threat posed by such overwhelming numbers of available troops is backed by China's huge population.

11 The Russian state has by now finished "using up" the Soviet nuclear inheritance. Only until 2015 should Russia be capable of responding to an external threat: in the (very hypothetical) case of a war with China, Russian military forces would have enough missiles to destroy China's entire military and civil infrastructure.

Vadim Soloviev, Editor-in-Chief of the Independent Military Review (Nezavisimoe Voennoye Obozrenie) even forecasts the complete destruction of the Russian army within a few years if the funding allocated to it is maintained at its present level ${ }^{20}$. This situation would be the most dangerous possible: in the event of war, it would leave Russia no alternative but to use its nuclear arsenal.

In this context, the military exercises (officially styled as "Peace Mission 2005") jointly organised during the summer of 2005 (August 18th-26th), in which 2,000 Russian soldiers and 8,000 Chinese soldiers took part, look like nothing more than a photoopportunity. Climaxing like a theatrical production with a joint parade of paratroops of the Russian and Chinese special forces and with a fanfare of music and firecrackers, the exercises were mainly aimed at demonstrating the military capacities of the SCO members ${ }^{21}$.

14 Moreover, in July 2005, forces of the Russian Far East army carried out large-scale military exercises. These were the first Russian manoeuvres since the fall of the USSR to deploy practically all the land, air and naval forces scattered across the whole of the military region of the Russian Far East. The objective was to prepare a counter-attack against a hypothetical aggressor, particularly in areas close to the Pacific Ocean and on Love River. These Russian exercises were much more ambitious than "Peace Mission 2005", which was organised in China a month later. The comparison between these two operations, both in complexity of forces deployed and in numbers, seems to indicate that Russian military chiefs are more alert to the likelihood of an attack on Russia by its neighbours than they are eager for co-operation within the SCO.

Russia in Central Asia: trying to regain its footing 

really match up to its ambitions in seeking to strengthen its influence in Central Asia. Also, one needs to take account of domestic policy factors within the former Soviet Republics and in particular of the threats posed to the stability of the governments in place. President Askar Akayev after ten years of stability. Little by little, the country is sinking into chaos; Kyrgyzstan has become a battlefield between clans in the south of the country who support the new President Kurmanbek Bakiev-former Prime Ministerand the northern clans supporting the Prime Minister Felix Kulov, a former KGB general. This competition between the two men risks destroying the fragile Kyrgyz state. Another serious threat is posed by organised crime, poised to take over both the economy and the politics of this small country. No government decision is safe from sabotage by corrupt officials. Attempts at eliminating the most dangerous groups of bandits, made by Kulov, were not supported by the President of the Republic and came up against protests by many deputies who threatened to take their complaints to the constitutional court. If civil war does break out, it is inevitable that foreign military forces (Russian, American or others) will interfere, to prevent the agitation provoked by criminal elements from developing into an Islamic revolution that might destabilise the entire region. Some Russian military analysts ${ }^{22}$ consider that if Kyrgyzstan were overtaken by a complete political collapse, Russia and Kazakhstan could impose some kind of protectorate until stability could be re-established and new elections held. because most of its own resources would already be mobilised in Iraq and Afghanistanand probably in Iran and Syria. Russian help would then be welcomed-and much preferred to that of China. Indeed, if Russia did not dare to put itself forward as a stabilising force, China might use Uyghur separatism ${ }^{23}$ as a pretext for sending troops to Kyrgyzstan and taking control of the Republic. In 2006, in the Kyrgyz town of Och, the headquarters of the war against terrorism and drug trafficking is to be established, in the charge of the Regional Anti-Terrorism Structure (RATS), an arm of the CSTO. Setting up this HQ appears also to suit national Kyrgyz interests ${ }^{24}$ : it could be a protective barrier for the state against unrest or civil war ${ }^{25}$. In Soviet times, a frontier guards base and an airbase were positioned at Och; this infrastructure has been well preserved and could rapidly be brought back into service by these collective regional stabilisation forces.

In the context of a peacemaking mission to Kyrgyzstan, Kazakhstan would seem more legitimate than Uzbekistan: for one thing, the Kazakhs are ethnically and culturally much closer to the Kyrgyzes than the Uzbeks (in particular, they share with them a moderate approach to Islam); for another, Uzbekistan insists on its territorial claims to Kyrgyzstan, whereas Kazakhstan does not. For this reason, any attempt at interference from Tashkent in Kyrgyz affairs would create a significant risk of ethnic conflict, which might spread across the region if Kazakhs committed troops to help in Kyrgyzstan.

The likelihood of Russian intervention in the case of destabilisation of Kyrgyzstan is increased by rumours ${ }^{26}$ of an intervention by special forces of Russian military intelligence, the GRU, in Bishkek, during the Tulip Revolution, at a time when the Kyrgyz army and police were in a state of paralysis. There exists, moreover, a precedent for intervention by post-Soviet Russia in Central Asia: in 1992, Russian

China Perspectives, 65 | may - june 2006 
special forces and frontier guards went into the city of Dushanbe in Tajikistan to carry out a bloody "peacemaking" operation. After the Russian frontier guards were withdrawn, according to the terms of the bilateral Russo-Tajik agreement of 2004, the Tajik-Afghan frontier came under the exclusive control of Tajik national forces. For all that, Russia has not cut back its military presence in that Republic: the 201st Division of the Russian Federal Army has been redeployed as a Russian military base in Tajikistan. Beyond its acceptance of the presence of Russian ground forces, the Tajik government has also permitted Russia to reactivate an airspace guidance centre set up during Soviet times in the Pamir Mountains, which will give Russia the means to control the airspace of Asia and the South Pacific.

Even so, the probability of Russian military interference in the case of a crisis in Kyrgyzstan is set back by the condition of the Russian forces at present based in the country, despite the existence of the Kant airbase. This Russian base on Kyrgyz territory, set up in 2003, was officially garrisoned at the end of 2004 by 700 men with 20 aircraft. Yet, by the end of 2005, the numbers were down to 200 soldiers and officers and 5 aircraft ${ }^{27}$. For lack of funding, instead of maintaining real military strength in Kyrgyzstan, Moscow can support only a moderate force there.

Neither does any significant strengthening of relations with the Uzbeks seem to be on Moscow's agenda, despite the tensions between Uzbekistan and the Americans and Europeans following the Andijan crackdown. The friendship treaty signed on November 14th 2005 by Vladimir Putin and Islam Karimov is a direct consequence of these tensions along with the expulsion of US troops from Uzbekistan-both these developments confirming the decline of Uzbek co-operation with the West. One might have supposed that Russia would take advantage by recovering the Harshi-Hanabad base. But the Russian Defence Minister, Sergei Ivanov, announced that Moscow had no intention in the near future of sending a military contingent to Uzbekistan. Once again, the explanation is purely financial: Russia does not dispose of sufficient funds to finish the rebuilding of its base in Tajikistan (the former 201st Division of the Federal Army) to secure a real presence in Kant. Another reason for this stubbornness, one that puts into perspective Russian weakness in the region, is that in reality Russia may, in the terms of the November 14th 2005 Treaty, send its forces at any time to any airbase it chooses. So the advantages conceded to Russia by the Uzbeks are more significant than those they conceded to the Americans in 2001.

Russia's revived interest in Uzbekistan has resulted from the attitudes of the United States and Europe towards the Uzbek government. Tashkent was afraid that the West desired the overthrow of the government and was really supporting attempts to achieve it. Its fears were reinforced by the highly critical response of the international community after the Andijan crackdown. It does seem that President Karimov's strategy since 1991, sharing out his favours between the United States and Russia, has run out of steam: his break with the West seems definitive. Uzbekistan wants to modernise its army and it knows that only Russia will agree to sell it military hardware and help to train its officers, without criticising its authoritarian regime. For all that, such a sudden political about-face is not irreversible, after 15 years of ostensibly evenhanded policy towards Russia and the other Central Asian Republics while seeking rapprochement with the United States. Uzbek hesitations over joining the $\mathrm{CSTO}^{28}$ are an illustration. It is interesting to note that, after the Andijan events ${ }^{29}$, the CSTO unambiguously supported the Uzbek government's decision to crush the revolt ${ }^{30}$. While 
the change of course is difficult for the Uzbeks, it is just as hard for Russia to restore its own confidence in Tashkent. It is hardly likely that Uzbekistan will become, in the immediate future, Russia's closest partner in Central Asia-for the present it is Kazakhstan that plays this role. Indeed, the links between Kazakhstan and Russia are close and of long standing. In the mid-eighteenth century, the Kazakh Khanates (djuz) voluntarily sought Russian protection, to avoid the fate of the Dzungars, of whom more than a million were massacred a few years before by the Qing army ${ }^{31}$. In 1992, Kazakhstan and the Russian Federation signed a friendship and co-operation agreement, guaranteeing Russian military protection for Kazakhstan-protection in particular from the Chinese threat ${ }^{32}$. Today, more than a million Kazakhs are Russian citizens and have been living in Russia for many generations.

It is probable that Moscow takes advantage of the rivalry between Uzbekistan and Kazakhstan to play a dominant role in Central Asian affairs. Despite having only half the population, Kazakhstan is for the present better-suited for playing this role than Uzbekistan, because the Kazakhs are less influenced by radical Islamism. Moreover, the unemployment rate in Kazakhstan is lower than in Uzbekistan, and the country is not threatened by shortages of water resources. Further, Kazakhstan is also more politically stable: the government of Nursultan Nazarbayev seems safe from "colour revolutions", thanks mainly to its efficient security services. By contrast, the failure of the Uzbek authorities to control the situation in Andijan may be directly related to the policy on national security followed for more than a decade, favouring repression rather than propaganda, the mechanisms for which, inherited from the USSR, was dismantled. In years to come, Russia will be paying close attention to the succession to President Karimov's leadership: its expectation is that this will put the finishing touches to Uzbekistan's rapprochement with Russia.

A union between Moscow, Minsk and Astana?

In the short term, Russia's priority seems to be to strengthen its position within the CSTO and especially to pursue the process of integration with Kazakhstan and Belarus ${ }^{33}$ while allowing the Commonwealth of Independent States to die a slow death. Founding a political, economic and military union around the "heart" of the Soviet UnionRussia, Belarus and Kazakhstan-is frequently mentioned by deputies of the Duma (the lower house of the Federal Parliament) and regional governors. One of the most ardent defenders of this cause is Vladimir Zhirinovsky, Duma deputy and leader of the Liberal Democratic Party of Russia-whose radical nationalist political programme is often useful to the Kremlin in attracting waves of criticism, before its essential proposals are taken up within federal government legislation. At the far end of the political spectrum, the idea of an alliance between former Soviet Republics receives a favourable reception among members of the Russian Communist Party, which is today Russia's main opposition party.

Forming a union of this kind can only be a painful process: it means that each of the countries taking part must give up part of its own sovereignty. Real integration presupposes that Russia will be able to propose forms of co-operation that will be really attractive to its neighbours. These might include creating a military union aimed at guaranteeing the survival of governments within a harshly competitive environment, or an economic union of sufficient weight to influence the movement of natural resources prices on the world market. Paradoxically, it seems that there is stronger resistance coming from Russia than from Belarus or Kazakhstan. Part of the Russian 
political elite is opposed to building up Russia within the post-Soviet area, preferring to see their country as an energy resource to the "civilised world" 34 . Russia does have the means to rebuild a union with its two closest neighbours, but Moscow is not making available the necessary funding. Instead of investing the income from its natural resources in economic programmes, social or military, it prefers to invest them in the American economy-on the pretext of guarding against inflation. In these circumstances, the prospect for building a real union across a substantial part of the post-Soviet area is still distant, and will depend on whether the governing classes truly desire to see their country strengthened. Indeed, the rebuilding of Russian power within its own region can be based only upon a change of domestic policy and a heightened desire to serve the national interest. Patriotism of this kind, such as is cultivated among China's elite, seems to be lacking in Russia.

Strengthening the CSTO, a response to the threat of war in Iran

At the beginning of March 2006, it was obvious that Russia's attempt to negotiate with Iran over the Iranian nuclear programme had failed ${ }^{35}$ : the Iranian Foreign Minister was refusing Moscow's proposals. Russian television then announced that the Russian government had made every possible effort to avoid war in the region, but that Iran had not shown any co-operation: the Iranians' suicidal attitude was preventing Russia from blocking US attempts to launch a sanctions campaign against Iran. From now on, Russian diplomacy will be focused on the regional consequences arising from a potential military conflict. It envisages in particular the ecological disaster created by radioactive contamination of large areas of Central Asia and around the Caspian Sea, as well as the possible massive exodus of the Iranian population towards neighbouring countries-a humanitarian catastrophe that could be far greater than that experienced in Kosovo or Iraq and that would affect Russia's southern borders as well as Kazakhstan, Azerbaijan and Armenia.

Another foreseeable consequence of a war in Iran would be an explosive increase in the Muslim diaspora (the Umma), especially in Western Europe, and the radicalisation of various Islamic groups in the countries of Central Asia, the (putative) American attack on Iran being considered as an offensive by Western Christian civilisation against the Muslim world ${ }^{36}$. Israel's participation in this war-which is possible given Iran's possession of ballistic missiles capable of reaching Israeli soil-could push Arab countries into joining the war on the Iranian side. Waging war in Iran could turn out far more difficult for the Americans than in Iraq. Civilian casualty figures could be terrifying; and a war of this kind could destroy any chance of dialogue between civilisations or cultures.

Russia today seems to be better placed than the United States or the European countries to extend its dialogue with the Muslim world, by reason of its Muslim population (20\% of Russia's total population). At the international level, Russia's affiliation to the Organisation of the Islamic Conference (OIC) as an observer country does give Moscow certain advantages. Russia might be a good intermediary to negotiate between the West and "politically incorrect" governments with whom Western countries refuse to hold discussions. The visit to Moscow by a Hamas delegation and Russia's discussions with Iran are examples of this. Historically, Russia's leaders have long experience of using the mechanisms of clandestine diplomacy; the Soviet Communist Party's old contacts files might prove useful, particularly the one for North Korea $^{37}$. 

community to exercise all the instruments and mechanisms for legal democratic administration, inside the borders of the different autonomous Republics. It is clear that this policy is based on a balance between the different interests of regional leaders favouring the central Russian government. The political system created at the time when the Soviet state was being built continues in general to function. Regional governments are able, with the exception of Chechnya, to control the situation inside their own autonomous territories and to prevent Muslim extremists from endangering national stability in Russia. A system of this kind, offering real autonomy, within the context of a federation, to Muslim minorities, is unthinkable in the countries of the European Union.

against Iran, possibly followed by war, could entail serious consequences for the Chinese economy, which imports a significant quantity of Iranian oil. The impact on China would have repercussions for European companies with investments there. Low oil prices enable China to keep prices down within its domestic market, which favours foreign investment. Fluctuations in oil prices, which might then stabilise at a higher level, could force the Chinese leaders into forming a new conception of China's economic development. They might seek to base their economic growth on strengthening their geostrategic position across the Asia-Pacific region: such expansion might very probably be not entirely peaceful ${ }^{38}$. Indeed, if China saw itself forced into foreign aggression, its energy resources being limited, it might have to seek a substitute for Iranian oil with the utmost urgency. This energy requirement also drives China into strengthening its claim on the Russian energy market and on Kazakhstan. Yet, the infrastructure for transporting oil and gas from these territories towards China is not yet sufficiently developed to satisfy the needs of the Chinese economy. Accordingly, one may expect China soon to press for a speed-up in the building of the Angarsk-Daqing oil pipeline and the gas pipeline destined to link Kazakhstan with Xinjiang (the West-East project).

The two most important decisions announced during President Putin's visit to Peking in March 2006 were taken against this background: strengthening co-operation in the arms market (China wishing to acquire more military equipment from Russia) and cooperation over oil supplies (a co-operation that seemed to have been inactive since 2004). At the time of writing, China has been given no clear response from Russia on the timescale for starting building work on the Russian stretch of the Angarsk-Daqing oil pipeline. Furthermore, the China National Petroleum Corporation (CNPC) has not been able to acquire any stock in the Russian oil company Sibneft, which would have given it a stake in the Russian market. Russia's recent concessions towards China-as agreed during Putin's visit-can be understood within the context of the threat of war against Iran: in exchange for a dominant position in the Chinese market in the fields of energy and military supplies, Russia agrees to supply oil and gas so long as deliveries are not interrupted by armed conflict. Thus, the contracts signed by Gazprom will make China the world's largest importer of Russian gas ${ }^{39}$. Two years ago, the project to build a gas pipeline from East Siberia into China did not exist; what has radically altered the state of play is the development of the situation in the Middle East.

A further consequence of Putin's visit to China is that energy co-operation with China will free Moscow of the fear that it might not be able to sell its natural resources, in the event that the European Union decided to stop importing Russian gas. The 
diversification of its energy sources, which Europe intends as a way of minimising its dependence on Russia, has been balanced, from Moscow's point of view, by diversifying Russia's outlets with the increase of business in the Far East. In this race, Russia is today further ahead than Europe.

On the military side, Russia has also begun taking preventive measures in case there should be war in Iran. On February 6th 2006, the Secretary-General of the CSTO, Nikolai Bordyuzha, went to Tashkent to propose to President Karimov that he should bring Uzbekistan speedily back into the CSTO, of which it was a member up until 1999. The two men also spoke about Uzbekistan joining the "Canal 2005" operation against terrorism and drug trafficking. The Uzbeks showed themselves helpful and responsive. The Uzbek army and special forces have made contact with their counterparts in CSTO member countries to stem the flow of drugs and radical Islamism out of Afghanistan.

Military chiefs of the unified command of the CSTO countries have prepared an agreement on "Collective forces in the collective security zone in Central Asia" ${ }^{40}$. One pillar of these collective forces will be the "rapid deployment force" of 11 battalions: three Russian, three Kazakh, three Tajik and two Kyrgyz. They will consist of special forces regiments, highly trained and well equipped. Russia is still ready to send reinforcements, battalions of heavy armour, communications battalions, several squadrons of transport aircraft and combat helicopters. Chinese army forces will not be part of this structure ${ }^{41}$.

In the long term, the creation of a military and political alliance in Central Asia would enable member countries of the CSTO to build a common policy in the energy field, towards the European Union and China in particular. Such a union would, in effect, permit them to dictate the price of oil and gas across the whole of the Eurasian area.

The creation of an alliance across the territory of the former Soviet Union, with Russia as a leading member, seems at the present time to be unlikely, due to the weakness of the Russian state. The battle between Russia and Ukraine over gas prices does not reflect the strengthening of Russia's position in the area of the Commonwealth of Independent States (CIS). Rather, it portends the dismantling of this organisation in its existing form. What are preventing Russia from building up a military presence in Central Asia are financial constraints. Over the months ahead, the most that can be achieved will probably be small military shows of force and photo opportunities: Putin at the controls of military aircraft. The rapprochement with China will take practical shape only within the limits of the SCO, that is to say, with no acceptance of mutual obligations. Furthermore, while Russia does favour the development of this organisation, it is mainly so that China, in playing its part, should fall in line with the collective decisions being taken, rather than pursue its own independent policy in Central Asia. Similarly, Russian initiatives within the context of the CSTO, of which China is not a member, are aimed at creating a force able to match China's power in Central Asia, to remedy the present weakness of each of the members in isolation. Changes in this inconsistent foreign policy would require changes in the Kremlin: a new leadership intent on developing the national economy and maintaining a reasonable distance both from the West and from China.

The vast majority of people within the Russian political elite do not favour the resurrection of the USSR; a union founded on compulsion would be useless. Russia needs loyal allies. Moscow's present eagerness in seeking out allies is a sign of weakness: if Russia were powerful, it would not have to go to such lengths to find 
friends. They would put themselves forward in a more natural way. Russia's contradictory manoeuvring vis-à-vis China denotes the fearfulness of a country that sees itself having to survive between two hostile powers: the West, which offers no prospect of co-operation, and China, more and more aggressive in its economic and military growth. In these circumstances, the Russians' approach is dictated by the wish to guarantee the present frontiers of their state.

Translated from the French original by Philip Liddell

\section{NOTES}

1. The Collective Security Council of the CSTO is at present chaired by the Russian President, Vladimir Putin; its Secretary General is Nikolai Bordyuja, the former head of Russia's frontier guards. Between 2004 and 2005, military chiefs of the member countries of the CSTO organised a series of manoeuvres named "Rubej 2004, 2005" (Line of defence 2004, 2005). These manoeuvres were designed to evaluate the capacity of the army commanders of the former Soviet republics to co-ordinate their efforts in the event of war. The secret services of the CSTO countries also launched a special operation, "Canal 2005", aimed at creating a security cordon around Afghanistan to stem the flow of drugs and Islamic terror. This operation was automatically renewed for the year 2006.

2. See the newspapers Rossiyskaya Gazeta (www.rg.ru) and Krasnaya Zvezda (www.redstar.ru), and the magazine Itogi (www.itogi.ru). See also the Internet sites www.utro.ru, www.strana.ru, www.kreml.org, www.vor.ru, www.polit.ru.

3. For more information on the structures of the Shanghai Co-operation Organisation (SCO) as well as a historical perspective, see the work of the expert on Sino-Russian relations Alexander Lukin and in particular "Shanhaiskaya Organizaciya Sotrudnichestva: strukturnoe oformleniye i perspektivy razvitiya" (The SCO: Structural formation and prospects for development) This article is available on the website of the Moscow Institute for International Relations (MGIMO), which trains the officials of the Foreign Affairs Ministry of the Russian Federation, at the address http://mgimo.ru/ fileserver/2004/nauka/az-04.pdf. Alexander Lukin is also Director of the Centre for Research on East Asia of the MGIMO.

4. At the height of the Bishkek crisis, Russian television (www.ortv.ru) showed the intervention of several special forces groups, of "unidentified origin", entering the city to disperse the crowd.

5. These would be Russian political movements of the left, the extreme left and the extreme right.

6. The Russian Chamber of Commerce and Industry (created and led by Evgeny Primakov) is a non-governmental organisation that lobbies the Russian central government on behalf of big Russian and foreign enterprises. Primakov continues to exert powerful influence over Russian foreign policy, especially in Asia. The Kremlin still sends him on confidential missions in the role of essential mediator. 
7. We should cite Colonel-General Ivashov (today an independent military analyst who was, in 1999, Deputy Chief of Staff at the Russian Foreign Ministry), the ex-chief of the KGB analysts Lt. General Leonov (member of the working group in the Namakon research centre, headed by the former chief of KGB special operations) and MajorGeneral Drozdov. Several researchers at the Moscow Far-East Institute have also produced interesting work on this subject: A.B. Bolyatko, G.D. Agafonov, V.P. Zimonin, A.S. Krasilnikov, V.B. Yakubovskij, V.P. Kudinov, A.G. Yakovlev, A.I. Sizonenko, A.A. Sveshnikov, A.G. Yurkevitch, P.B. Kamennov, M.V. Demtchenko, N.B. Gorbatchev. The review Nezavisimoe Voennoe Obozrenie (Independent Military Observations) is of particular interest: it publishes articles by experts and by Russian army and special services veterans on military and geostrategic questions. This magazine is directed by V. Solovyev.

8. Iliyas Sarsembaev, "La question territoriale: enjeu géopolitique et idéologique dans les relations sino-russes", thesis supervised by Professor Dominique Colas, Paris, Institut d'Études Politiques, 2005.

9. In this context, the ignorance of history among many Russian politicians is a problem. In the terms of the Bandung declaration, April $18^{\text {th }} 1955$, China declared that it would not be part of any military or political bloc. After relations between the two communist parties were re-established in 1989, following Gorbachev's visit to Peking and his meeting with Deng Xiaoping), Moscow did make, on several occasions, attempts to invite Peking to join the Warsaw bloc, but the Chinese government referred back to the Bandung declaration in declining the Kremlin's proposal. Today, there are no clear signs that the Chinese government is ready to change that position.

10. Viktor Stefashin, "Sovremennye voenno-doktrinal'nye vzglâdy rukovodstva K.N.R." (Present-day views of the leaders of the PRC on military doctrine), a report delivered to the Scientific Conference of the Far East Institute in Moscow in 1993.

11. This theme was first raised on December $23^{\text {rd }} 1998$, during the official visit of Evgeny Primakov, then Prime Minister, to New Delhi.

12. Iliyas Sarsembaev, "Puissances régionales en Asie-mythes et réalités", Les Nouvelles de Chine, $\mathrm{n}^{\circ} 17$, June-July 2004.

13. On May $20^{\text {th }} 2005$, the Far East Institute in Moscow organised a conference on the theme: "Problems over improving the Shanghai Cooperation Organisation and cooperation between China and Russia in Central Asia". Present were Russian Sinologists, diplomats from the Russian Foreign Ministry, and experts and analysts from the Russian Defence Ministry. According to the report prepared by the head of the Research Centre into the Problems of the SCO and Regional Security of the Far East Institute, A Bolyatko, and the Centre's scientific attaché, A. Klimenko, the CSO is at present at the very start of being changed into a real political union. http://www.ifesras.ru/conf/2005/4-2005.html

14. Viktor Larin is the Director of the Institute of Ethnography of the Far East (Vladivostok) of the Russian Academy of Sciences. He has accused local authorities of falsifying their border lines with China and has personally implicated the Governor of the Primorye Region, E. Nazdratenko. Viktor Larin, Kitaj i Dal'nij Vostok Rossii v pervoj Polovine 90-h: Problemy regional'nogo vzaimodejstviya (China and the Russian Far East in the first half of the 1990s: the problems of cooperation), Vladivostok, 1999. See also Viktor Larin, Kitaj i Dal'nij Vostok Rossii (China and the Russian Far East), Vladivostok, 1998. 
15. Yuri Galenovich is one of the leading figures of the Institute of the Far East in Moscow. He is considered one of the most eminent Sinologists in Russia. Yuri Galenovich, Rossiâ i Kitaj v 20 veke: Granica (Russia and China in the Twentieth Century: the Frontier, Moscow, 2001. Yuri Galenovich, Moskva-Pekin, Moskva-Tajbej (MoscowPeking, Moscow-Taipei), Moscow, 2003. Yuri Galenovich, Rubej pered startom: Kitajskaya problema dlya Rossii I S.SH.A. na poroge XXI veka (The Starting Line: The Chinese Problem for Russia and the United States on the eve of the Twenty-First Century), Moscow, 1999, Centre of Convertible Education.

16. According to the Russian Federal Security Service, there are no statistics on the number of Chinese citizens in the Russian Federation, and specifically none on their numbers in the Russian Far East. The frontier guard service, which is part of the FSB and is the main body responsible for legal control of foreigners in Russia, collects absolutely no data on the numbers of foreigners. The figures that appear in the work of foreign researchers-or Russian researchers-can thus not be taken for anything better than estimates.

17. Television reports of President Putin on board the nuclear bomber launching the missile were transmitted repeatedly on various Russian federal networks: www.ortv.ru www.rtr.ru www.ntv.ru www.newsru.com.

18. Zavtra, October 5th 2005 (No. 40), p.12, www.zavtra.ru.

19. www.vif2ne.ru claims to be the "independent forum for the Russian armed services, veterans of the Soviet army and of the special forces". It is interesting to compare the officers' assessment of the state of the Russian armed forces with the official reports published on the Defence Ministry website: http://www.mil.ru/articles/ article3431.shtml.

20. Nezavisimoe Voennoe Obozrenie (Independent Military Review), No. 44, November 18th 2005, p. 3. This article is online on the review's website: www.nvo.ng.ru

21. The manoeuvres were staged in the Shandong peninsular. The Russians were represented by regiments from the Russian Far East, the $11^{\text {th }}$ Russian Air Force Army (two Tu-95 MS strategic bombers, four Tu-22 M3 bombers, four Su-27 SM fighters, four Su-24 M2 tactical bombers), ships of the Russian Pacific fleet, regiments of the special forces of the Russian Internal Affairs Ministry and rail regiments.

22. They are a group of analysts, including former Soviet and Russian information officers in retirement or still working. The group's website publishes articles-most written under pseudonyms: www.namakon.ru.

23. A significant part of the Uyghur diaspora is settled in the capital cities of Kyrgyzstan and Kazakhstan.

24. Legally speaking, CSTO forces have the right-written into the treaty-to intervene in Kyrgyz affairs if the country's stability is threatened.

25. Interviews carried out in CSTO agencies.

26. Russian television has broadcast coverage, but without comment. The Defence Ministry has neither confirmed nor denied the story.

27. Personal observations.

28. The CSTO members are Armenia, Belarus, Kazakhstan, Kyrgyzstan, Russia and Tajikistan. Apart from a few joint military exercises as well as some political dealings aimed at facilitating the defence of common positions within the SCO, the CSTO is still in an embryonic state. 
29. Iliyas Sarsembaev, "Défis et menaces en Asie centrale dans le nouveau contexte mondial de l'après-11 septembre 2001", Strategic Observatory on China, meeting of January $13^{\text {th }} 2005$. Introductory text published on the Central Asian website of the IFRI.

30. http://www.prime-tass.ru/news/show.asp?id=503291\&ct=news.

31. The descendants of the survivors of the Dzungars live today in Kalmykia, a small Russian Republic with a population of no more than a million inhabitants.

32. Official Chinese historiography considers the whole of Kazakhstan as part of Chinese territory, temporarily lost because of Russian imperialism during the eighteenth and nineteenth centuries.

33. On December $1^{\text {st }}, 2005$, President Vladimir Putin announced that Russia would allow its political allies (and in particular fellow members of the SCTO) to benefit from low "domestic" prices for their arms purchases. This offer was to include the training of military and special services personnel.

34. This expression was proposed by Russian democrats in the late 1980 s and early 1990s to designate the West, in opposition to Russia.

35. Moscow was proposing the creation of a common Russo-Iranian company that would enrich uranium on Russian soil. That would have helped to keep a sanctions vote off the UN agenda and prevent the outbreak of war initiated by the United States.

36. Iliyas Sarsembaev, "Défis et menaces en Asie centrale dans le nouveau contexte mondial de l'après-11 septembre 2001", op cit.

37. Iliyas Sarsembaev, "La question territoriale: enjeu géopolitique et idéologique dans les relations sino-russes", op. cit.

38. Viktor Stefashin, “Sovremennye voenno-doktrinal'nye vzglâdy rukovodstva K.N.R.", op. cit.

39. China National Petroleum Corporation and Gazprom agreed to "unfreeze" the Kovytkinsky project (east Altay) and to start building in 2007 a gas pipeline from Russia into China. For more information, see the report by Sergei Luzyatin (MGIMO): "Rossiya i Kitai: v poiskah novogo vektora sotrudnichestva. K itogam vizita V. Putina”. (RussiaChina: in search of new avenues of cooperation. On the results of Vladimir Putin's visit to China). www.mgimo.ru.

40. The other two collective security zones are still only at the initial construction stage. They are the "Eastern European zone" (Russia-Belarus) and the "Caucasus zone" (Russia-Armenia).

41. Figures and information offered here were provided to the writer by members of the SCTO staff in Moscow.

\section{RÉSUMÉS}

This article offers a reflection on Russia's attitude towards possible alliances in Asia. There are numerous constraints, imposed by Russian domestic issues, and such collaborations could prove difficult. In view of this it is clear that there is little practical prospect of any real strategic partnership between Russia and China at the present time. 